\title{
Medicinas Complementarias
}

\section{Canela y Diabetes}

Un reciente estudio' muestra que los pacientes diabéticos que incorporan a su dieta un gramo diario de canela durante un período de 40 días experimentan un descenso de sus niveles de colesterol y glucosa en sangre. Este efecto estaría mediado por una más eficiente acción de la insulina a nivel periférico (en las células adiposas).

Para el estudio, el equipo de investigación instó a 60 pacientes con diabetes mellitus tipo 2 a consumir diariamente 1, 3 ó 6 gramos de canela durante 40 días. Para el grupo control se eligió la harina como placebo. Tanto la canela como la harina fueron administradas en cápsulas.

Los pacientes a los que se administró canela experimentaron un descenso superior a 30\% de sus niveles de glucosa, lípidos y colesterol. Por el contrario, no se evidenció ningún cambio en el grupo placebo.

En este contexto, sin embargo, debe aludirse a que la canela contiene algunas sustancias que pueden resultar tóxicas, razón por la que debe esperarse que la gente no exagere su consumo: un gramo sería suficiente.

\section{Mariela Alderete y Marcelo Ikonicoff.}

[ Area de Medicinas Complementarias. Unidad de Medicina Familiar y Preventiva. Hospital Italiano de Bueno Aires. ]

\section{Referencia}

1. Alam Khan, Mahpara Safdar, Mohammad Muzaffar Ali Khan, Khan Nawaz Khattak, and Richard A. Anderson Cinnamon Improves Glucose and Lipids of People With Type 2 Diabetes Diabetes Care 26: 3215-3218

\section{Noticiero epidemiológico}

\section{Vacuna contra la Hepatitis A}

El Ministerio de Salud y Ambiente de Argentina ha decidido incluir la vacuna contra la Hepatitis A al Calendario Nacional de Vacunación. La medida se concreta en consenso con las principales entidades científicas de nuestro país e implica que Argentina sea el segundo país en el mundo que aplique esta política (el otro es Israel).

La vacuna se indicará en una sola dosis a todos los niños al cumplir un año de vida, junto a la Vacuna Triple Viral. La aplicación de una sola dosis genera una respuesta de protección inmunitaria que ronda entre el 95 y el $99 \%$ de las personas vacunadas. Esta medida fue tomada en parte debido al aumento de la notificación de casos de Hepatitis A de un $23 \%$ en todo el país durante el 2004, especialmente en el Noroeste y en Cuyo. Se planean vacunar 750.000 chicos en 2005, con una inversión anual de alrededor de 21 millones de pesos. Se está llevando a cabo una evaluación económica para determinar la costo-efectividad de la medida.

Datos tomados de la página del Ministerio de Salud y Ambiente de la Nación Argentina (www.msal.gov.ar)

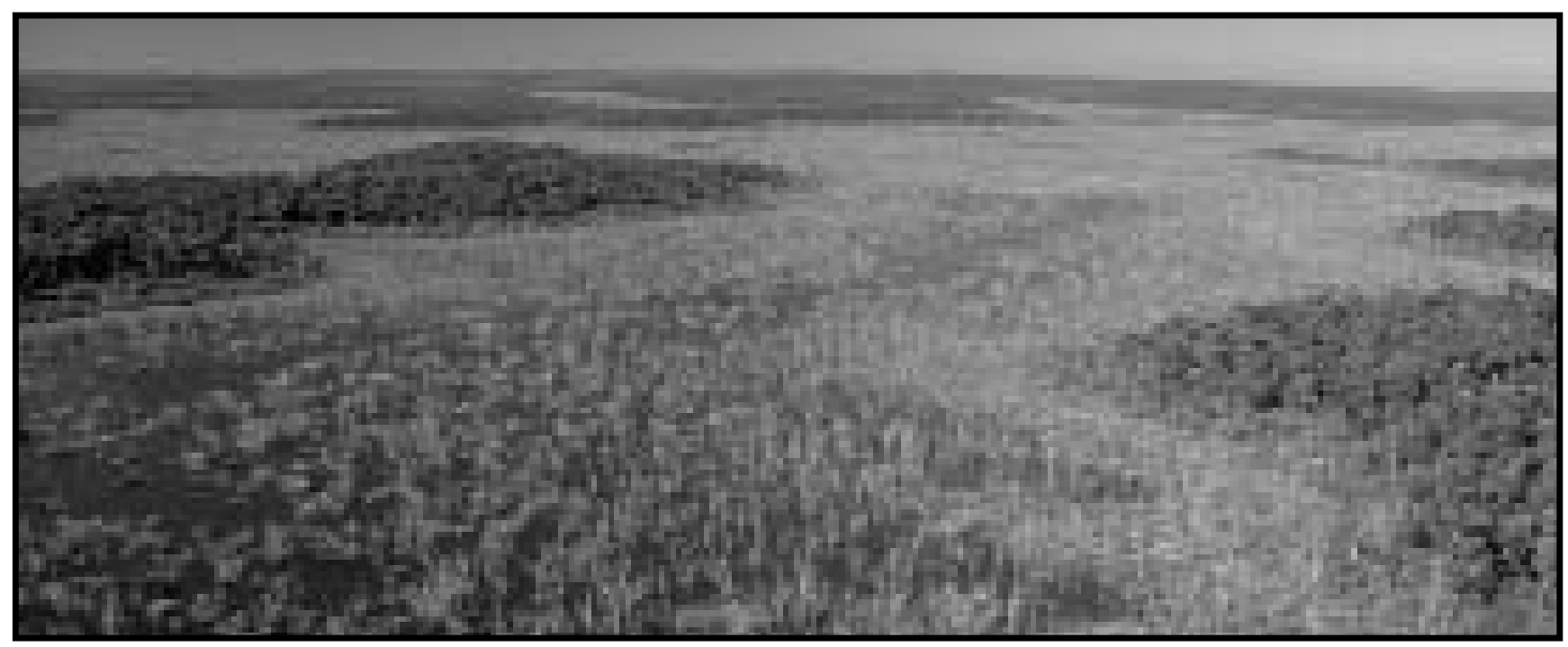

Gentileza Secretaria de Turismo de La Nación 